\title{
KARAKTERISTIK FISIK DAN KIMIA CINCAU TIRUAN DARI KULIT BUAH NAGA MERAH (Hylocereus polyrhizus)
}

\author{
Physical and Chemical Characteristics of Artificial Grass Jelly from red dragon \\ fruit (Hylocereus polyrhizus) peel
}

\author{
Nela Agustin Kusuma Wardani ${ }^{1)}$, Putri Tari Indriani ${ }^{1)}$, Dinda Ina Sarinastiti ${ }^{1)}$ \\ 1) Akademi Analis Farmasi dan Makanan Putra Malang, Jl. Barito No 5 Malang, Jawa timur, \\ Indonesia 65122 \\ Email : nela.agustin.kw@gmail.com
}

Diterima 30 Agustus 2018; diterima pasca revisi 23 Oktober 2018

Layak diterbitkan 30 Oktober 2018

\begin{abstract}
Red dragon fruit peel (Hylocereus polyrhizus) has a large precentage of total weight fruit (30-35\%) which is not utilized and high content of pectin $( \pm 10,80 \%)$. Based on thatred dragon fruit peel will be made a artificial grass jelly. This study were determine the physical ( $\mathrm{pH}$, total dissolved solids, color and sineresis) and chemical characteristics (fat, protein, water, ash, carbohydrate and crude fiber content)of a artificial grass jelly from red dragon fruit peel. Artificial grass jelly was made from the extract of red dragon fruit peel with the addition of carrageenan, $\mathrm{CMC}-\mathrm{Na}$, sugar with a ratio of 1,5: 1: 0,5. The result of physical characteristic analysis were obtained $p H$ value $(7,55 \pm 0,02)$, total dissolved solids $(9,32 \% \pm 0,00)$, color $\left(L 35,23 \pm 0,36, a^{*} 8 \pm 1,25 b^{*} 2,33 \pm 0,32\right)$ and sineresis were 24 hours (6\%), 48 hours (6,30\%), 72 hours (10,28\%). The result of chemical characteristic were obtained fat content $(0,26 \% \pm 0,00)$, protein $(4,35 \% \pm 0,00)$, water $(94,44 \% \pm 0,00)$, ash $(0,48 \% \pm 0,00)$, carbohydrate $(0,48 \% \pm 0,00)$ and crude fiber $(1,63 \% \pm 0,00)$.
\end{abstract}

Keyword : Artificial grass jelly; red dragon fruit peel; physicochemical properties

\section{ABSTRAK}

red dragon fruit (Hylocereus polyrhizus) peel ini memiliki persentase 30-35\% dari berat buahnya dan seringkali hanya dibuang serta kandungan pektin yang tinggi sebesar $\pm 10,80 \%$. Berdasarkan kandungan dari kulit buah naga merah ini dimanfaatkan sebagai pangan fungsional yakni cincau tiruan. Penelitian bertujuan mengetahui karakteristik fisik dan kimia cincau tiruan kulit buah naga merah. Beberapa senyawa yang ditambahkan dalam pembuatan cincau tiruan mempengaruhi karakteristik cincau tiruan, sehingga perlu dilakukan analisa fisik dan kimia pada cincau tiruan kulit buah naga merah. Pembuatan cincau tiruan dibuat dari sari kulit buah naga merah dengan penambahan karagenan, $C M C-$ $\mathrm{Na}$, gula dengan perbandingan 1,5:1:0,5. Cincau tiruan dianalisa karakteristik fisik ( $p H$, total padatan terlarut, warna dan sineresis) dan karakteristik kimia (lemak, protein, air, abu, karbohidrat dan serat kasar). Karakteritik fisik pada cincau tiruan dari kulit buah naga merah didapatkan nilai $p H 7,55 \pm 0,02$, total padatan terlarut 9,32\%, warna ( L 35,23\% $\pm 0,64$, $a^{*} 8 \pm 1,25, b^{*} 2,33 \pm 0,32$ dan sineresis 24 jam 6\% $\pm 0,00,48$ jam 6,30\% 0,00, 72 jam 10,28 $\pm 0,00$. Karakteristik kimia pada cincau tiruan dari kulit buah naga merah didapatkan nilai kadar lemak 0,26\% 0 ,00, protein 4,35\% $\pm 0,00$, air 94,44\% $\pm 0,00$, abu 0,48\% $\pm 0,00$, karbohidrat 0,48\% $\pm 0,00$ dan serat kasar 1,63\% $\pm 0,00$.

Kata kunci : Cincau tiruan; kulit buah naga merah; karateristik fisik; sifat fisikokimia 


\section{PENDAHULUAN}

Indonesia merupakan salah satu negara yang membudidayakan buah naga merah (Hylocereus polyrhizus). Pada tahun 2017, terjadi peningkatan produksi buah naga menjadi 42.349 ton dari luas lahan 1.275,5 hektar (Banyuwangi kab, 2018). Kulit buah naga merah ini memiliki persentase yang banyak dari berat buahnya yakni sebesar 30-35\% dan seringkali hanya dibuang sebagai sampah (Faridah $d k k ., 2008)$. Semakin banyaknya kulit buah naga merah yang dibuang, maka mengakibatkan menumpuknya limbah kulit buah naga merah dan penumpukan sampah. Padahal kulit buah naga merah memiliki kandungan pektin yang cukup tinggi yakni $\pm 10,80 \%$ (Megawati \& Ulinuha, 2015). Pektin adalah salah satu senyawa hidrokoloid yang bisa dimanfaatkan sebagai pembentuk gel (Suwoto $d k k$., 2017). Kulit buah naga merah juga memiliki kandungan serat pangan yang cukup tinggi yakni sekitar 46,70\% (Waladi $d k k ., 2015)$. Berdasarkan kandungan yang dimiliki oleh kulit buah naga merah tersebut maka kulit buah naga merah bisa dimanfaatkan sebagai pangan fungsional yakni cincau tiruan.

Cincau tiruan yang dimaksud adalah meniru bentuk secara fisik dari gel cincau hitam, dengan memanfaatkan kandungan pektin di dalam kulit buah naga. Namun akan ada perbedaan proses pembuatan antara gel cincau hitam dan cincau yang terbuat dari kulit buah naga merah. Cincau hitam (Mesona palustris) biasanya dibuat dengan cara sederhana, pembuatan gel yang terbentuk diperoleh dengan cara diremasremas dengan air (Nur \& Leily, 2014). Biasanya pada pembuatan cincau hitam ditambahkan larutan abu qi. Larutan abu qi ditmbahkan untuk membantu menambah kekuatan gel yang dibentuk pada cincau yang dibuat (Kartikaningrum $d k k$., n.d.). Pengolahan cincau yang dengan cara diremas-remas menghasilkan gel yang terbentuk bersifat irreversibel akibatnya gel mudah mengalami sineresis. Penurunan daya ikat air atau sineresis dapat diatasi dengan penambahan bahan penstabil yang berupa hidrokoloid (Purwaningrum \& Nuswantoro, 2013). Senyawa hidrokoloid adalah suatu senyawa yang dapat digunakan sebagai perekat, pengikat air, pengemulsi, pembentuk gel, dan pengental dalam produk pangan (Widyaningtyas \& Susanto, 2015). Pada proses pembuatan cincau tiruan kulit buah naga merah ditambahkan senyawa hidrokoloid lain yakni karagenan dan Na CMC (Natrium Carboxyl Methyl Cellulose) sebagai bahan tambahan untuk pembentuk gel.

Penambahan senyawa hidrokoloid tersebut berfungsi sebagai pengemulsi dan pengikat air sehingga bisa mengurangi sineresis dan bisa mempengaruhi dari karakteristik cincau tiruan yang dihasilkan semakin lebih baik. Berdasarkan beberapa senyawa yang ditambahkan dalam pembuatan cincau tiruan kulit buah naga merah yang dibuat akan mempengaruhi karakteristik cincau tiruan yang dihasilkan sehingga perlu dilakukan analisis terhadap karakteristik fisik dan kimia pada cincau tiruan kulit buah naga merah.

\section{MATERI DAN METODE}

Penelitian ini bersifat deskriptif dengan tujuan untuk mengetahui cara pembuatan cincau tiruan kulit buah naga merah dan mengetahui karakteristik fisik $(\mathrm{pH}$, total padatan terlarut, warna, dan sineresis) dan kimia (lemak, protein, air,
*Corresponding author :

Nela Agustin Kusuma Wardani

Email : nela.agustin.kw@gmail.com

Akademi Analis Farmasi dan Makanan Putra Malang, Jl. Barito No 5 Malang, Jawa timur, Indonesia 65122
How to cite :

Wardani, N.A.K., Indriani, P.T., \& Sarinastiti, D.I. (2018). Karakteristik Fisik dan Kimia Cincau Tiruan dari Kulit Buah Naga Merah (Hylocereus polyrhizus). Jurnal Ilmu dan Teknologi Hasil Ternak, 13 (2), 98-107 
abu, karbohidrat, dan serat kasar) yang ada pada cincau tiruan kulit buah naga merah.

Alat yang digunakan dalam penelitian ini adalah pemanas (Thermo Scientific), oven (Memmert tipe U.30), $\mathrm{pH}$ meter merk EZDO, color reader merk CR-10 MINOLTA, refraktometer merk ATC, perangkat destilasi, soxhlet, kondensor, dan tanur merk Muffle Furnace FB1410M-33 $C A P$ 2.1. Bahan yang digunakan yaitu kulit buah naga merah dengan karateristik bagian terluar dari buah yang agak tebal sebesar 3-4 mm. Buah naga didapatkan dari UD. Naga Jaya Makmur, Bululawang, Kabupaten Malang. Bahan lainnya yaitu karagenan, CMC-Na (Natrium Carboxyl Methyl Cellulose), akuades (Merck), buffer pH 7 (Merck), kalium persulfat $\left(\mathrm{K}_{2} \mathrm{~S}_{2} \mathrm{O}_{4}\right.$, Merck), tablet kjedahl, asam sulfat $\left(\mathrm{H}_{2} \mathrm{SO}_{4}\right.$, Merck), lempeng Zink (Merck), kalium sulfit $\left(\mathrm{K}_{2} \mathrm{~S}\right.$, Merck), natrium hidroksida $(\mathrm{NaOH}$, Merck), asam klorida $(\mathrm{HCl}$, Merck), n-heksan (Merck), dan etanol 96\% (Merck).

\section{Pembuatan Cincau Tiruan Kulit Buah Naga Merah}

Sebanyak 500 g kulit buah naga merah di potong menjadi bagian yang lebih kecil kemudian ditambahkan air sebanyak 1 L. Blansing dilakukan pada suhu $70^{\circ} \mathrm{C}$ selama 5 menit, kemudian di blender sampai hancur lalu disaring dan didiamkan 15 menit. Setelah dingin ditambahkan karagenan, $\mathrm{CMC} \mathrm{Na}$ dan gula dengan perbandingan $(1: 1,5: 0,5)$ dari jumlah sari kulit buah naga merah, diaduk hingga homogen. Campuran larutan tersebut dimasak pada suhu selama 10-15 menit hingga mencapai suhu $100^{\circ} \mathrm{C}$, kemudian dicetak.

\section{Pengujian Mutu Fisik}

Pengujian mutu fisik pada cincau tiruan kulit buah naga merah meliputi uji pH (Kumesan dkk., 2017), total padatan terlarut (Meikapasa \& Seventilofa, 2016), warna (Andarwulan dkk., 2011), dan sineresis (Kuncari $d k k .$, 2014).

\section{Pengujian Mutu Kimia}

Pengujian mutu kimia (analisa proksimat) pada cincau tiruan kulit buah naga merah meliputi kadar lemak dengan metode soxhlet kadar protein metode semi makro kjeldahl, kadar air metode pemanasan, kadar abu, kadar karbohidrat metode by difference (Santi dkk., 2012), dan kadar serat kasar .

\section{HASIL DAN PEMBAHASAN}

\section{Karakteristik Fisik}

Penelitian ini dilakukan analisa pada cincau tiruan kulit buah naga merah terhadap mutu fisik meliputi analisa terhadap $\mathrm{pH}$, total padatan terlarut, warna dan sineresis. Hasil penelitian terhadap karakteristik fisik pada cincau tiruan kulit buah naga merah disajikan pada Tabel 1 .

\section{pH}

Derajat keasaman digunakan untuk menyatakan tingkat keasaman atau basa yang dimiliki oleh suatu zat, larutan atau benda (Khaerunnisa \& Rahmawati, 2013). Berdasarkan Tabel 1, pH yang dimiliki cincau tiruan dari kulit buah naga merah yaitu 7,54 $\pm 0,02$. $\mathrm{pH} 6,5-7,5$ bersifat basa, $\mathrm{pH}$ dari cincau tiruan kulit buah naga merah sebesar 7,54 jadi bersifat basa (Granita, 2013).

Cincau tiruan kulit buah naga merah yang dibuat memiliki $\mathrm{pH}$ basa karena pada proses pembuatannya menggunakan bahan tambahan karagenan, karagenan memiliki sifat alami yakni bersifat basa. Karagenan memiliki $\mathrm{pH}$ cenderung basa akibat adanya perlakuan alkali. Karagenan merupakan bahan pengental yang memiliki $\mathrm{pH}$ basa yakni sebesar 9,5 - 10,5 (Parnanto $d k k$., 2016). 
Tabel 1. Hasil Analisa Mutu Fisik pada Cincau Tiruan Kulit Buah Naga Merah

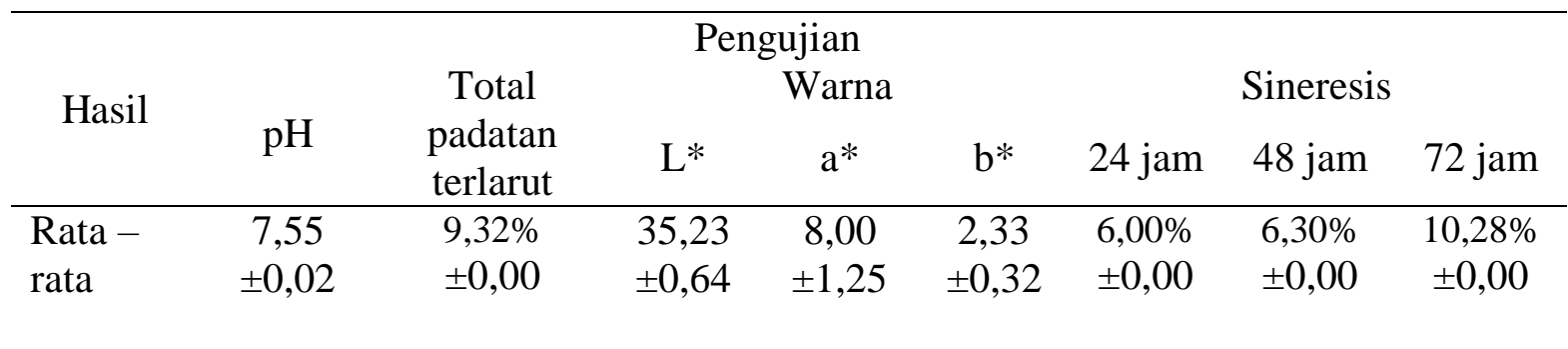

Keterangan : Data yang diperoleh dari 3 kali replikasi dan 3 kali pengujian.

$\mathrm{L}$ : Kecerahan $\mathrm{a}^{*}$ :Merah $\quad \mathrm{b}^{*}$ : Kuning

Nilai $\mathrm{pH}$ mempengaruhi tekstur dari suatu makanan, nilai $\mathrm{pH}$ yang semakin asam akan menghasilkan produk yang bertekstur rapuh bahkan dapat menyebabkan tidak terbentuknya gel (Eveline et al., 2011). Penambahan karagenan yang memiliki $\mathrm{pH} 9,5-10,5$ maka dihasilkan cincau tiruan kulit buah naga merah dengan $\mathrm{pH}$ 7,54 yang bersifat basa. Selain $\mathrm{pH}$ dari karagenan yang bersifat basa, menurut penelitian sebelumnya $\mathrm{pH}$ dari ekstrak kulit buah naga merah berkisar 6,5 - 7,5 (Yanti $d k k ., 2017$ ). Pada penelitian sebelumnya disebutkan bahwa $\mathrm{pH}$ dari cincau hitam sebesar 7,33 (Nuraini, 2000) dan 7,57 (Tamboto, 2012). Hal ini menunjukkan bahwa nilai $\mathrm{pH}$ dari cincau tiruan kulit buah naga merah tidak berbeda jauh dengan nilai $\mathrm{pH}$ cincau hitam, namun $\mathrm{pH}$ basa yang dimiliki oleh cincau tiruan kulit buah naga merah ini mengurani kestabilan dari pigmen antosianin yang dimiliki oleh kulit buah naga merah, karena pigmen antosianin lebih stabil dalam $\mathrm{pH}$ yang rendah. $\mathrm{pH}$ dari cincau yang terlalu rendah maka akan menimbulkan sineresis yang lebih tinggi (Ningtyas $d k k$., 2015).

Nilai $\mathrm{pH}$ yang turun mengakibatkan hidrolisis ikatan polisakarida pektin pada cincau dan diikuti dengan viskositas larutan (Tiara, 2016). Nilai pH yang dimiliki oleh cincau tiruan kulit buah naga merah tidak terlalu rendah sehingga bersifat basa yang memberikan pengaruh tekstur dari gel yang dihasilkan menjadi lebih kokoh karena tidak ada hidrolisis yang dihasilkan dari pektin atau gel cincau tiruan kulit buah naga merah. Hal ini bisa mengurangi sineresis pada cincau dan terlepasnya ikatan air dalam gel pada cincau tiruan kulit buah naga merah.

\section{Total Padatan Terlarut}

Total padatan terlarut digunakan untuk menghitung metabolit yang terseksresikan dan terakumulasi dalam suatu cairan. Tingginya padatan terlarut disebabkan karena protein dan karbohidrat yang terkandung terurai menjadi senyawa sederhana yang terlarut dalam air (Rahayu, 2015). Berdasarkan Tabel 1, total padatan yang dimiliki oleh cincau tiruan dari kulit buah naga merah yaitu 9,32\% $\pm 0,00$. Jumlah total padatan terlarut dipengaruhi dari jumlah proporsi gula dalam penambahan sukrosa yang ditambahkan dalam pembuatan makanan.

Hal ini disebabkan karena semakin tinggi proporsi sukrosa yang ditambahkan, maka tekanan osmosis semakin tinggi, sehingga plasmolisis yang terjadi pada bahan semakin besar pula dan air serta molekul - molekul organik yang keluar dari bahan akan lebih sedikit (Pertiwi \& Wahono, 2014).

Sukrosa memiliki sifat menarik dari bahan yang direndam, air yang keluar dari dalam bahan akan membawa molekul molekul protein yang terlarut dalam air maupun yang terlarut dalam larutan gula, sehingga terhitung sebagai total padatan terlarut (Pertiwi $d k k$., 2014). Total padatan terlarut pada cincau hitam dan cincau tiruan tiruan kulit buah naga merah tidak berbeda jauh. Pada penelitian sebelumnya diketahui bahwa total padatan terlarut pada cincau 
hitam sebesar 10,25\% (Rahmawansyah, 2006), dan total padatan terlarut pada filtrat cincau sebesar 10,07 dan12,53 (Yulianto, 2013).

\section{Warna}

Warna dapat diamati secara kuantitatif dengan metode Hunter dengan colour reader yang menghasilkan tiga nilai pengukuran yaitu $L$, $a^{*}$ dan $b^{*}$. Nilai $L$ menunjukkan tingkat kecerahan sampel. Berdasarkan Tabel 1 nilai warna yang dimiliki cincau tiruan dari kulit buah naga merah yaitu nilai $\mathrm{L}$ sebesar $35,33 \pm 0,64$, nilai $a^{*}$ sebesar $8 \pm 1,25$ dan nilai $b^{*}$ sebesar 2,33 $\pm 0,32$. Nilai L menunjukkan tingkat kecerahan dari sampel, semakin mendekati angka 100 berarti sampel makin cerah dan sebaliknya. Nilai $a^{*}$ dari 0 sampai +80 menunjukkan warna merah sedangkan $b^{*}$ dari 0 sampai +70 menunjukkan warna kuning. Cincau tiruan kulit buah naga merah menghasilkan warna merah yang dibuktikan oleh dominan lebih tinggi nilai $a^{*}$ daripada $b^{*}$, warna merah itu sendiri karena pada warna yang didapatkan dari kulit buah naga merah. Warna merah lebih dominan pada cincau tiruan kulit buah naga merah karena pada kulit buah naga merah memiliki pigmen warna merah yang biasanya disebut dengan antosianin. Turunan senyawa aromatik tunggal termasuk antosianin berkontribusi dalam warna merah karena subtitusi cincin B pada senyawa aromatik, sehingga warna yang dihasilkan pada pigmen warna yang ada pada kulit buah naga merah dari antosianin adalah merah

\section{Sineresis}

Sineresis adalah peristiwa keluarnya air dari dalam gel dimana gel mengkerut sehingga cenderung memeras air keluar dari dalam gel. Ikatan hidrogen antara molekul air dan protein melemah serta pori - pori diantara molekul melonggar, sehingga dapat dilalui oleh air bebas (Putri $d k k$., 2015). Angka sineresis yang tinggi menunjukkan gel tidak stabil secara fisik terhadap penyimpanan pada suhu $10^{\circ} \mathrm{C}$ selama 24, 48, dan 72 jam. Suhu $10^{\circ} \mathrm{C}$ digunakan untuk menyimpan makanan dengan kelembaban yang paling stabil, cincau tiruan kulit buah naga merah salah satu makanan yang harus disimpan pada suhu dingin karena makanan tersebut rentan akan panas.

Tabel 1 sineresis yang dimiliki cincau tiruan dari kulit buah naga merah 24 jam, 48 jam, dan 72 jam yaitu $6,00 \% \pm 0,00$, $6,30 \% \pm 0,00$ dan $10,28 \% \pm 0,00$. Cincau tiruan kulit buah naga merah memiliki nilai sineresis yang rendah sehingga menghasilkan bentuk yang kokoh, bentuk yang kokoh tersebut karena dipengaruhi oleh penambahan senyawa hidrokoloid yakni karagenan dan CMC - Na (Natrium Carboxyl Methyl Celulos). Hal ini dikarenakan penambahan karagenan sebagai salah satu senyawa hidrokoloid yang berfungsi sebagai pembentuk gel dan pernstabil. Selain itu, ditambahkan CMC $\mathrm{Na}$ (Natrium Carboxyl Methyl Cellulose), ion $\mathrm{Na}$ meningkatkan kemampuan mengikat air dan kekuatan gel (Prangdimurti $d k k ., 2014$ ).

Karagenan dan CMC - Na (Natrium Carboxyl Methyl Celulos) merupakan bahan yang mengurangi sineresis serta sebagai bahan pengikat air dengan cara meningkatkan sifat hidrofilik protein (Putri $d k k$., 2013). Nilai sineresis yang rendah pada cincau tiruan membuktikan bahwa semakin kuat daya ikat air terhadap gel yang dibuat maka gel yang terbentuk tidak mudah rusak dan cincau tiruan kulit buah naga merah memiliki bentuk yang bisa bertahan lama dalam waktu $(24,48$ dan 72 jam) (Kuncari $d k k, 2014)$.

Karagenan akan membantu menggabungkan dan mengikat polimer, sehingga membentuk jala 3 dimensi bersambungan, yang nantinya dapat menangkap air didalamnya dan membentuk struktur yang kuat, sedangkan pada CMC $\mathrm{Na}$ (Natrium Carboxyl Methyl Celulos) ini bisa mengikat hidrogen yang dapat menyerap air. Kedua proses ini yang menyebabkan cincau menjadi tetap kuat dan kokoh (Distantina et al., 2010). Cincau 
disimpan dalam wadah cup kedap udara dengan bantuan vakum sehingga cincau tiruan kulit buah naga merah lebih awet dari kontaminasi bakteri dan lebih stabil sehingga bisa mempertahankan bentuk dari cincau yang didapatkan.

\section{Karakteristik Kimia}

Selain dilakukan penelitian terhadap karakteristik fisik pada cincau tiruan kulit buah naga merah dilakukan juga analisa terhadap karakteristik kimia pada kulit buah naga merah dan pada cincau tiruan kulit buah naga merah yang meliputi analisa kadar lemak, kadar protein, kadar air, kadar abu dan serat kasar.

Hasil penelitian terhadap mutu kimia pada kulit buah naga merah dan cincau tiruan kulit buah naga merah disajikan pada Tabel 2.

Tabel 2. Hasil Analisa Mutu Kimia Kulit Buah Naga Merah dan Cincau Tiruan dari Kulit Buah Naga Merah

\begin{tabular}{cccccccc}
\hline Hasil & $\begin{array}{c}\text { Kadar } \\
\text { lemak }\end{array}$ & $\begin{array}{c}\text { Kadar } \\
\text { protein }\end{array}$ & $\begin{array}{c}\text { Kadar } \\
\text { air }\end{array}$ & $\begin{array}{c}\text { Kadar } \\
\text { abu }\end{array}$ & $\begin{array}{c}\text { Kadar } \\
\text { karbohidrat }\end{array}$ & $\begin{array}{c}\text { Kadar } \\
\text { serat }\end{array}$ \\
\hline Kulit & Rata-rata & $0,25 \%$ & $4,36 \%$ & $93,68 \%$ & $0,66 \%$ & $1,04 \%$ & $3,60 \%$ \\
buah & & $\pm 0,00$ & $\pm 0,00$ & $\pm 0,00$ & $\pm 0,00$ & $\pm 0,00$ & $\pm 0,00$ \\
naga & & & & & & & \\
merah & & & & & & & \\
\hline Cincau & Rata-rata & $0,26 \%$ & $4,35 \%$ & $94,44 \%$ & $0,48 \%$ & $0,48 \%$ & $1,63 \%$ \\
tiruan & & $\pm 0,00$ & $\pm 0,00$ & $\pm 0,00$ & $\pm 0,00$ & $\pm 0,00$ & $\pm 0,00$ \\
\hline
\end{tabular}

Keterangan : Data yang diperoleh dari 3 kali replikasi dan 3 kali pengujian.

\section{Kadar Lemak}

Tabel 2 hasil pengukuran kadar lemak pada kulit buah naga merah dan cincau tiruan kulit buah naga merah tidak memiliki perbedaan yang terlalu jauh. Kulit buah naga merah memiliki kadar lemak sebesar $0,25 \% \pm 0,00$ sedangkan pada cincau tiruan kulit buah naga merah sebesar 0,26\%. $\pm 0,00$ Kandungan lemak pada kulit buah naga merah dan cincau tiruan ini tergolong rendah.

Menurut BPOM RI suatu produk dikatakan bebas lemak jika mengandung 0,5 g lemak/100 g bahan (Khoiriyah \& Lelly, 2014). Kulit buah naga merah dan cincau tiruan hanya memiliki nilai kadar lemak sebesar $0,25 \%$ dan $0,26 \%$ sehingga hanya mengandung lemak $0,25 \mathrm{~g}$ lemak / 100 bahan dan 0,26 g lemak / 100 bahan. Oleh karena itu, kadar lemak yang terlalu rendah bisa dikatakan dalam kulit buah naga merah dan cincau tiruan kulit buah naga merah bebas lemak karena nilai yang dihasilkan kurang dari 0,5 g lemak / 100 bahan. Kadar lemak dari kulit buah naga merah dan cincau tiruan tidak memiliki perbedaan yang jauh, karena bahan bahan yang ditambahkan pada pembuatan cincau tiruan tidak memiliki kandungan lemak yang cukup tinggi. Penambahan bahan bahan seperti karagenan yang hanya memiliki kadar lemak sebesar 0,12\% hingga $0,2 \%$ (Suryani $d k k$., 2015) hal ini tidak mempengaruhi kadar lemak pada cincau tiruan, sehingga tidak ada perbedaan kadar lemak dalam bahan baku yakni kulit buah naga merah dan hasil produknya yaitu cincau tiruan kulit buah naga merah. jika dibandingkan kadar lemak pada cincau tiruan dengan cincau hitam lebih besar kadar lemak pada cincau hitam. Berdasarkan penelitian sebelumnya disebutkan bahwa kadar lemak pada cincau hitam sebesar 1\% (Fauzziyah $d k k$., 2016 ), sedangkan pada cincau tiruan kulit buah naga merah hanya sebesar $0,26 \%$. Kadar lemak semakin rendah semakin baik pada makanan, karena biasanya lemak dalam makanan mengakibatkan beberapa dampak bagi tubuh dan kesehatan, asupan lemak yang melebihi kebutuhan dalam jangka waktu lama dapat memicu timbulnya obesitas (Permanasari $d k k$., 2017). 


\section{Kadar Protein}

Sampel kulit buah naga merah yang dianalisa memiliki kadar protein sebesar $4,36 \% \pm 0,00$ sedangkan pada cincau tiruan kulit buah naga merah yang dibuat memiliki rata - rata kadar protein sebesar $4,35 \% \pm 0,00$. Hasil kadar protein antara kulit buah naga merah dan cincau tiruan yang dibuat tidak memiliki perbedaan yang cukup jauh. Kandungan protein yang ada pada kulit buah naga merah tidak menurun saat setelah dibuat produk cincau tiruan, sehingga nilai gizi yang ada pada cincau tiruan sama dengan kulit buah naga merah yang digunakan sebagai bahan baku pembuatannya. Hasil penelitian sebelumnya menyebutkan bahwa kadar protein pada cincau hitam sebesar 6\% (Fauzziyah, 2017) sedangkan kadar protein pada cincau tiruan rata- rata sebesar $4,35 \%$, kadar protein pada cincau hitam lebih banyak dari cincau tiruan kulit buah naga merah.

\section{Kadar Air}

Kadar air pada kulit buah naga merah sebesar 93,68\% $\pm 0,00$ sedangkan pada cincau tiruan kulit buah naga merah sebesar 94,44\% $\pm 0,00$. Nilai kadar air pada cincau tiruan kulit buah naga merah tidak berbeda jauh, pada dasarnya kulit buah naga merah yang dijadikan sebagai bahan baku pembuatan cincau tiruan memiliki hampir $75 \%$ bagian kulitnya adalah air (Daniel et al., 2007). Granita (2013), menyatakan bahwa gel cincau hitam memiliki kadar air sebesar 77,38\% $\pm 1,08$. Dilihat dari persentase kadar air yang sangat tinggi hampir $95 \%$ bagian dari cincau tiruan tersebut adalah air. Pada pembuatan cincau tiruan kulit buah naga merah memakai air dan kulit buah naga merah sebagai bahan utama sedangkan penambahan bahan lain seperti karagenan, CMC - Na (Natrium Carboxyl Methyl Celulos) dan gula hanya sekitar 0,5\%-1,5\% saja. Produk yang memiliki kadar air yang tinggi mudah mengalami kerusakan, sehingga perlu adanya penyimpanan yang baik agar lebih tahan lama.

\section{Kadar Abu}

Hasil pengukuran kadar abu pada kulit buah naga merah memiliki rata - rata sebesar $0,66 \% \pm 0,00$ dan cincau tiruan kulit buah naga merah sebesar $0,44 \% \pm$ 0,00 . Penelitian sebelumnya mengatakan bahwa kadar abu cincau hitam yakni rata rata sebesar 0,22\% (Khoiriyah, 2014). Hasil kadar abu yang dimiliki oleh cincau tiruan kulit buah naga merah tidak berbeda jauh dengan kadar abu pada cincau hitam. Abu dan mineral merupakan komponen dalam bahan pangan yang dibutuhkan bagi tubuh dalam jumlah kecil, berfungsi sebagai zat pengatur dan pembangun.

\section{Kadar Karbohidrat}

Kadar karbohidrat pada kulit buah naga merah sebesar $1,08 \% \pm 0,00$, sedangkan pada cincau tiruan kulit buah naga merah sebesar $0,48 \% \pm 0,00$. Kadar karbohidrat pada cincau tiruan lebih sedikit jika dibandingkan dengan kadar karbohidrat cincau hitam. Pada penelitian sebelumnya menyebutkan bahwa kadar karbohidrat pada cincau hitam sebesar 26\% (Fauzziyah, 2017).

Cincau tiruan kulit buah naga merah lebih banyak mengandung air dibandingkan kandungan kandungan lain. Meskipun kadar karbohidrat pada cincau tiruan rendah, kadar serat yang terkandung dalam cincau tiruan kulit buah naga merah cukup untuk membantu proses metabolisme didalam tubuh.

\section{Serat Kasar}

Kadar serat kasar pada kulit buah naga merah sebesar 3,60\% $\pm 0,00$ dan pada cincau tiruan kulit buah naga merah sebesar $1,63 \% \pm 0,00$. Hasil kadar serat pada kulit buah naga merah cukup besar karena pada penelitian sebelumnya menyebutkan bahwa kandungan serat pangan pada kulit buah naga merah cukup tinggi yakni sekitar 46,70\% (Waladi $d k k$., 2015). Nilai kadar serat kasar dari kulit dan cincau tiruan yang dihasilkan memiliki perbedaan karena pada proses pembuatan cincau tiruan yang kulit yang digunakan 
hanya bagian dalam sedangkan senyawa selulosa yang termasuk serat kasar ini banyak terdapat di kulit luar kulit buah naga merah. Kadar serat kasar suatu makanan dapat dijadikan indeks kadar serat makanan, karena umumnya dalam serat kasar ditemukan $0,2-0,5$ bagian jumlah serat makan (Mursalina $d k k$., 2012).

\section{KESIMPULAN}

Karakteritik fisik pada cincau tiruan dari kulit buah naga merah didapatkan nilai $\mathrm{pH} 7,54$, total padatan terlarut 9,32\%, warna (L 35,23\%, a* 8, b* 2,33 dan sineresis 24 jam 6\%, 48 jam 6,30\%, 72 jam 10,28\%. Karakteristik kimia pada cincau tiruan dari kulit buah naga merah didapatkan nilai kadar lemak 0,26\%, protein $4,35 \%$, air $94,44 \%$, abu $0,48 \%$, karbohidrat $0,48 \%$ dan serat kasar $1,63 \%$. Berdasarkan hasil penelitian, karateristik fisik dan kimia cincau tiruan kulit buah naga dikatakan baik, serta bentuk yang dihasilkan mirip dengan gel cincau hitam.

\section{DAFTAR PUSTAKA}

Andarwulan, N., Feri, K., \& Dian, H. (2011). Analisis pangan. Jakarta: Dian Rakyat.

Daniel, S., Osfar, S., \& Irfan, D. (2007). Kajian kandungan zat makanan \& pigmen antosianin tiga jenis kulit buah naga (Hylocereus Sp.) sebagai bahan pakan ternak. Journal of Materials, 7-10.

Distantina, S., Fadilah, Rochmadi, Fahrurrozi, M., \& Wiratni. (2010). Proses Ekstraksi Karagenan Dari Eucheuma Cottonii. Seminar Rekayasa Kimia \& Proses.

Eveline., Santoso, J., \& Widjaja, I. (2011). Kajian konsentrasi \& rasio gelatin dari kulit ikan patin \& kappa karagenan pada pembuatan jeli.
Jurnal Pengolahan Hasil Perikanan

Indonesia, 14(2), 98-105. https://doi.org/10.17844/JPHPI.V14I2.5318

Faridah, A., Holinesti, \& Syukri, D. (2008). Identifikasi pigmen betasianin dari kulit buah naga merah ( hylocereus polyrhizus ). Seminar Nasional FMIPA-UT.

Fauzziyah, I. N., Widyaningsih, T. D., \& Widyastuti, E. (2015). Liangteh berbasis cincau hitam (Mesona palustris $\mathrm{Bl}$ ), pandan (Pandanus amaryllifolius), \& jahe merah (Zingiber officinale). Jurnal Pangan \& Agroindustri, 4(2), 536-541.

Granita, A. T. (2013). Karakteristik Rheologi Gel Cincau Hitam (Mesona Palustris BL). Fakultas Teknologi Pertanian.

Kartikaningrum, A. A., Haryadi, H., \& Marseno, D. W. (2016). Pengaruh penggunaan berbagai basa \& pati dalam pembuatan cincau hitam instan terhadap sifat-sifat fisik gel yang dihasilkan. Agritech, 21(2), 4448. https://doi.org/10.22146/AGRITECH.13599

Khaerunnisa, G., Rahmawati, I., \& Budiyono, B. (2013). Pengaruh ph \& rasio cod:n terhadap produksi biogas dengan bahan baku limbah industri alkohol (vinasse). Jurnal Teknologi Kimia \& Industri, 2(2), 1-7.

Khoiriyah, N., \& Amalia, L. (2014). Formulasi cincau jelly drink (Premna oblongifolia L Merr) sebagai pangan fungsional sumber antioksidan. Jurnal Gizi \& Pangan, 9(2), 73-80. https://doi.org/10.25182/JGP.2014.9.2.

Kumesan, E. C., Pandey, E. V, \& Lohoo, H. J. (2017). Analisa total bakteri, kadar air \& ph pada rumput laut (Kappaphycus alvarezii) dengan dua metode pengeringan. Jurnal Media 
Teknologi Hasil Perikanan, 5(1), 124-129.

Kuncari, E. S., Iskandarsyah, S., \& Praptiwi, P. (2014). Evaluasi, uji stabilitas fisik \& sineresis sediaan gel yang mengandung minoksidil, apigenin \& perasan herba seledri (Apium graveolens L.). Buletin Penelitian Kesehatan, 42(2), 213-222.

Megawati, M., \& Ulinuha, A. Y. (2014). Ekstraksi pektin kulit buah naga (dragon fruit) \& aplikasinya sebagai edible film. Jurnal Bahan Alam Terbarukan, 3(1), 16-23. https://doi.org/10.15294/JBAT.V3I1.3097

Meikapasa, N. W., \& Gusti, N. O. (2016). Karakteristik total padatan terlarut (Tpt), stabilitas likopen \& vitamin c saus tomat pada berbagai kombinasi suhu \& waktu pemasakan. Jurnal GaneÇ Swara, 10(1), 81-86.

Mursalina, M., Sinaga, S. M., \& Silalahi, J. (2012). Penetapan kadar serat tak larut pada makanan keripik simulasi (measuring concentration of insoluble fiber in simulation crispy chips). Journal of Natural Product \&Pharmaceutical Chemistry, 1(1), 1-7.

Nuraini, D., Sunarto, P., \& Lucyana. (2000). Ekstraksi komponen pembentuk gel cincau hitam \& karakteristik gelatinisasinya. Warta IHP/J. of Agro-Based Industry, 17(1-2), 36-41.

Parnanto, N. H., Nurhartadi, E., \& Rohmam, L. (2018). Karakteristik fisik, kimia \& sensori permen jelly sari pepaya (Carica papaya. L) dengan konsentrasi karagenankonjak sebagai gelling agent. Jurnal Teknosains Pangan, 5(1), 19-27.
Permanasari, Y., \& Aditianti. (2017). Konsumsi Makanan Tinggi Kalori \& Lemak Tetapi Rendah Serat \& Aktivitas Fisik Kaitannya Dengan Kegemukan Pada Anak Usia 5-18 Tahun Di Indonesia (The Consumption Of Foods Which High Calories \& Fat But Low In Fiber \& Physical Activity \&Its Relatihionship To Obesity In Children Aged 5-18 Years Old In Indonesia). Jakarta.

Pertiwi, M. F. D., \& Susanto, W. H. (2013). Pengaruh proporsi (buah:sukrosa) \& lama osmosis terhadap kualitas sari buah stroberi (Fragaria vesca L). Jurnal Pangan \& Agroindustri, 2(2), 82-90.

Prangdimurti, E., Herawati, D., Firlieyanti, A. S., \& Briantoto, R. D. (2014). Perubahan mutu fisik \& mikrobiologi gel cincau hijau kemasan selama penyimpanan. Jurnal Mutu Pangan , 1(2), 118 - 123

Purwaningrum, S., \& Nuswantoro, D. (2013). Usulan Program Kreativitas Mahasiswa Judul Program.

Putri, N. K., Gunawan, I. W., \& Suarsa, W. (2015). Aktivitas antioksidan antosianin dalam ekstrak etanol kulit buah naga super merah (Hylocereus costaricensis) \& analisis kadar totalnya. Journal of Chemistry, 9(2), 243-251.

Rahayu, F. I. (2015). Pemanfaatan Salak (Salacca zalacca) Sebagai Bahan Alternatif Pembuatan Cuka Buah Dengan Penambahan Konsentrasi Acetobacter aceti Yang Berbeda. Universitas Muhammadiyah Surakarta.

Rahmawansyah, Y. (2006). Pengembagan Produk Minuman Cincau Hitam (Mesona Palustris) Dalam Kemasan Cup Polipropolen Di PT FITS 
Mandiri Bogor. Institut Pertanian Bogor.

Santi, R., Sunarti, T., Santoso, D., \& Triwisari, D. (2012). Komposisi kimia \& Polisakarida rumput laut hijau. Jurnal Akuatika, 3(2), 105-114.

Suryani, I., Sri, W., \& Mahrus, A. (2015). Quality characteristic of carrageenan seaweed kappaphycus alvarezii with different bleaching treatment: quality assessment of organoleptic \& proximate. Jurnal Teknik Pertanian Lampung (Journal of Agricultural Engineering), 4(3), 161-168. https://doi.org/10.23960/JTEP-L.V4I3

Suwoto, S., Septiana, A., \& Puspita, G. (2017). Ekstraksi pektin pada kulit buah naga super merah (hylocereus costaricencis) dengan variasi suhu ektraksi \& jenis pelarut. Jurnal Ilmiah Teknik Kimia, 1(2).

Tamboto, B. H. (n.d.). Formulasi \& Evaluasi Sediaan Mikroemulsi - Gel Dari Eksrak Etanol Daun Cincau Hitam (Mesona Palustris BL.,) Sebagai Antioksidan. Universitas Negeri Gorontalo.
Tiara. (2016). Pengaruh Penambahan Ekstrak Daun Cincau Hijau Rambat Terhadap Kadar Serat, Viskositas, Total Koloni Bakteri Asam Laktat (BAL) \& Nilai Organoleptik Susu Fermentasi. Universitas Andalas.

Waladi, Johan, V. S., \& Hamzah, F. (2015). Pemanfaatan kulit buah naga merah (Hylocereus polyrhizus.) sebagai bahan tambahan dalam pembuatan es krim. Jurnal Online Mahasiswa (JOM) Bidang Pertanian, 2(1), 1-11.

Yanti. (2017). Potensi Ekstrak Buah Naga Putih (Hylocereus undatus Haw.) Dalam Meningkatkan Agresivitas Mencit Jantan (Mus musculus L.). Universitas Lampung.

Yulianto, R. R., \& Widyaningsih, T. D. (2013). Formulasi produk minuman herbal berbasis cincau hitam (Mesona Palustris), jahe (Zingiber Officinale), \& kayu manis (Cinnamomum burmanii). Jurnal Pangan \& Agroindustri, 1(1), 65-77. 